\title{
Traduções poéticas: - Romance d'A Pedra do Reino e o Príncipe do Sangue do Vai-e-Volta e a microssérie televisiva
}

Acir Dias da Silva

Professor do Centro de Educação, Comunicação e Artes (CECA) da Universidade Estadual do Oeste do Paraná (Unioeste). Professor do Programa de Pós-graduação Stricto Sensu - Mestrado em Letras -, área de concentração em Linguagem e Sociedade da Unioeste. Pesquisador Associado do Laboratório de Estudos Audiovisuais (Olho), da Universidade Estadual de Campinas.

E-mail: acirdias@yahoo.com.br

Deise Ellen Piatti

Mestranda em Letras - área de concentração em Linguagem e Sociedade da Unioeste -, linha de pesquisa em Linguagem Literária e Interfaces Sociais: Estudos Comparados pela Capes.

E-mail: deisepibic@hotmail.com

Resumo: Apresentamos neste texto um estudo acerca da interpretação que Ariano Suassuna fez de imagens agentes que materializam tradições do mundo ibérico medieval para o Romance d'A Pedra do Reino e o Príncipe do Sangue do Vai-eVolta (1971), bem como da tradução que o diretor Luiz Fernando Carvalho realizou desta obra para a microssérie televisiva (2007). Tanto na manifestação literária como naquela configurada em imagens de luz e movimento, as imagens surgem como alegorias do passado que se desenvolveram no tempo por meio das diversas formas de expressão da cultura oral, escrita e visual, as quais constituem a nossa memória estética do tema a que dão forma e vida. Tais suportes incorporam elementos do universo poético na construção da linguagem; nesse sentido, serão discutidas questões teóricas referentes à articulação alegórica da literatura, teledramaturgia, pintura e cultura popular.
Abstract: This work presents a study concerning on a translation made by Ariano Suassuna about Image Agents that materialize traditions from the Iberian medieval world to the Romance $d^{\prime} A$ Pedra do Reino e o Príncipe do Sangue do Vai-e-Volta (1971), as well as the translation made by the director Luiz Fernando Carvalho of this work for a televise miniseries (2007). As the literary manifestation as the one configured in light images and movements, the images appear as past allegories that had developed during the time by diverse expression forms of the oral, writing and sight culture, which constitute our $A$ esthetic Memory of the subject to which is given form and life. Such supports incorporate elements from the poetical universe in the language construction and, following this direction, it will be discussed theoretical issues concerning to the literature allegorical articulation,
Recebido: 14.10 .2008

Aprovado: 03.02.2009 
comunicação \& educação • Ano XIV • Número 2 • maio/ago 2009

Palavras-chave: tradução poética, literatura, teledramaturgia, Romance d'A Pedra do Reino e o Príncipe do Sangue do Vai-eVolta, memória estética. television dramas, painting and popular culture.

Keywords: poetical translation, literature, television drama, Romance d'A Pedra do Reino e o Príncipe do Sangue do Vai-eVolta, aesthetic memory.

O Romance d'A Pedra do Reino e o Príncipe do Sangue do Vai-e-Volta (1971) ${ }^{1}$, de Ariano Suassuna, é inspirado em um episódio ocorrido no século XIX, no município sertanejo de São José do Belmonte, a 470 quilômetros do Recife, onde uma seita, em 1836, tentou ressurgir o rei Dom Sebastião - transformado em lenda em Portugal, depois de ter desaparecido na África (Batalha de Alcácer-Quibir). Sob domínio espanhol, os portugueses sonhavam com a volta desse rei, que restituiria a nação tomada à força. O sentimento sebastianista ainda hoje é lembrado em Pernambuco, durante a Cavalgada da Pedra do Reino, manifestação popular que acontece anualmente no local onde adeptos ao movimento de retorno do rei foram sacrificados. A história, baseada na cultura popular nordestina e inspirada na literatura de cordel, nos repentes e nas emboladas, é dedicada ao pai do autor e a mais doze cavaleiros, entre eles Euclides da Cunha, Antônio Conselheiro e José Lins do Rego.

O romance é narrado pelo seu protagonista, Dom Pedro Dinis Ferreira Quaderna, que constrói um monumento literário à cultura caboclo-sertaneja nordestina, marcada pelas tradições do mundo ibérico (Portugal e Espanha), trazidas pelos primeiros colonizadores europeus e transfeitas ao longo dos séculos. O personagem-narrador, Quaderna, é preso em Taperoá por subversão e faz sua própria defesa perante o corregedor; para tanto, relata a história de sua família, escrita na prisão. Declara-se descendente de legítimos reis brasileiros, castanhos e cabras da Pedra do Reino - sem relação com os imperadores estrangeiros e falsificados da Casa de Bragança -, e conta o seu envolvimento com as lutas e as desavenças políticas, literárias e filosóficas no seu reino. $\mathrm{Na}$ época do seu lançamento, o livro foi considerado um marco da literatura nordestina, após o ciclo do romance regional de 1930, e foi traduzido para o cinema, o teatro e a televisão.

\section{MEMÓRIA ESTÉTICA}

1. A edição do romance com a qual trabalhamos foi a de: Suassuna, Ariano. Romance d'A Pedra do Reino e o Príncipe do Sangue do Vai-e-Volta. 5 . ed. Rio de Janeiro: José Olympio, 2004.
A tradução do Romance d’A Pedra do Reino e o Príncipe do Sangue do Vai-eVolta para a língua do cinema soa como um encontro orgânico. O tradutor é um intérprete que toma, como ponto de partida para a construção de sentidos de uma obra, o caos aparente das imagens. Traduzir é transtornar o passado a fim de construir uma rede de significados sobre a obra de origem. Tais significações surgem desse passado que reverbera nas imagens da obra traduzida. 
E é enquanto processo meditativo e reflexivo, a partir do tempo presente, que as imagens são atualizadas para gerar outras tantas. Desse modo, também o Romance d'A Pedra do Reino e o Príncipe do Sangue do Vai-e-Volta surge como tradução das imagens do mito de Dom Sebastião, da Coluna Prestes, de imagens transmitidas pelos rapsodos e diascevastas, ou seja, artistas e cantores populares do Sertão brasileiro e da cultura ibérica medieval; enfim, são imagens que constituem, pois, o real subvertido da memória de Ariano Suassuna, e que são corporificadas neste seu romance.

Restauração, para Walter Benjamin, indica esse movimento incompleto e inacabado de regresso à memória do passado, e pressupõe imediatamente o movimento da destruição ${ }^{2}$. Tal como na montagem de atrações do cinema, conceito apresentado por Sergei Eisenstein em A forma do filme $e^{3}$, na literatura a restauração caracteriza-se como ligação entre dois fenômenos históricos que, ao serem dispostos lado a lado, adquirem sentido atual e desenham um novo objeto histórico.

Assim como Cervantes e Homero, autores das obras originárias que surgem de forma estilizada no Romance d'A Pedra do Reino e o Príncipe do Sangue do Vai-e-Volta, de igual maneira esta última constitui a obra originária da série de Luiz Fernando Carvalho. Mas o originário não é em si a obra propriamente traduzida: ele representa o reconhecimento e a descoberta de um fenômeno como um representante da revelação de um tema, uma imagem $^{4}$. Origem é, portanto, ao mesmo tempo e inseparavelmente, obra de destruição e de restituição, de dispersão e de reunião, de criação ${ }^{5}$. Sendo assim, a tradução consiste num procedimento de transgressão. Nesse processo, o tradutor buscará estabelecer a equivalência de sentidos entre imagens e/ou entre dois códigos distintos, ao mesmo tempo em que, inevitavelmente, adicionará suas reflexões ao texto traduzido e, por isso, ocorrerá uma ruptura da forma primeira na qual está materializado o tema. Como aponta Sebastião Uchoa Leite, traduzir um texto noutra língua é, pois, criar outro texto ${ }^{6}$. Neste caso, o tradutor vai se empenhar em atualizar não as palavras do texto, mas o conteúdo que nele se imprime como vida.

No romance, as lembranças evocadas por Quaderna são descritas de modo a lhes atribuir uma forma visível, que é, ao mesmo tempo, materialidade de seus significados. Essas imagens são atualizadas pelo leitor na forma de cenas, de imagens alegóricas. E ao construirmos um significado acerca delas, fazemos alusões as suas inúmeras outras materializações que participam da nossa memória estética.

Também as imagens da microssérie A Pedra do Reino são alegóricas porque aglomeram, num só momento expressivo (estético), acontecimentos, seres, símbolos, ações e narrações de diversas origens temporais e espaciais, de outros tempos e outros povos, que reaparecem transfiguradas na história. Por essa razão é que a produção estética de uma imagem alegórica mostra-nos seu caráter de criação coletiva e, também por isso, alegórica, aberta a significações não determinadas aprioristicamente. A fim de compreender seu significado, é preciso
2. GAGNEBIN, Jeanne Marie. História e narração em Walter Benjamin. São Paulo/Campinas: Perspectiva/Fapesp, 1994. Outras considerações a este respeito foram encontradas na obra: BENJAMIM, Walter. Magia e técnica, arte e política: ensaios sobre literatura e história da cultura. São Paulo: Brasiliense, 1994.

3. EISENSTEIN, Sergei. A forma do filme. Rio de Janeiro: Jorge Zahar, 2002.

4. GAGNEBIN, História..., cit., p. 18.

5. Ibid., p. 20.

6. LEITE, Sebastião Uchoa. Jogos e enganos. Rio de Janeiro: Ed. 34, 1995. p. 12.

7. A PEDRA do Reino. Direção: Luiz Fernando Carvalho. Rio de Janeiro: TV Globo, 2007. Português. 2 DVDs (4h36min), son., color. 
comunicação \& educação • Ano XIV • Número 2 • maio/ago 2009

8. ALMEIDA, Milton José de. Cinema: arte da memória. Campinas: Autores Associados, 1999

9. Considerações sobre este assunto são traçadas na obra: SANT'ANNA, Affonso Romano de. $\mathrm{Pa}$ ródia, paráfrase e cia. São Paulo: Ática, 2006

10. BAKHTIN, Mikhail. A cultura popular na Idade Média e no Renascimento: o contexto de François Rabelais. Brasília: UnB/ Hucitec, 1987. ultrapassar o sentido conceitual dos dados perceptíveis e buscar àquele ulterior. Para tanto, há que se ter em mente que a construção das imagens escritas, das imagens cinematográficas e iconográficas são produzidas a partir de uma relação histórica que trabalha para educar nossa memória visual e as formas de nossa imaginação do real. E ainda, por essa relação histórica à qual estamos condicionados é que um motivo ressurgirá em diferentes formas, ou seja, será reestruturado esteticamente pelo momento presente e passará a distinguir-se das outras versões em que fora apresentado anteriormente, mas resguardando em si a história e a essência de sempre.

O mesmo ocorre com as representações do cinema e da teledramaturgia. Tudo o que aparece na tela alude à outra coisa além do que está sendo visto: a mundos imaginados, reais e irreais, do passado e do presente. Cinema é uma arte da memória e da alusão. É dotado de uma memória estética. Milton José de Almeida diz que as imagens do cinema são fantásticas, trazem a potência do real e agem em nosso imaginário ou adormecem inesquecíveis em nossa memória. Quando novamente despertadas, ressurgirão, visualmente, na forma de alusão e recordação ${ }^{8}$.

Uma possível leitura que fazemos da microssérie A Pedra do Reino se dá pela aproximação por alusão entre a visualidade das imagens de Luiz Fernando Carvalho e as pinturas de Pieter Bruegel e Albrecht Dürer. O tratamento dado à fotografia da série aponta para a relação não só do estilo destes dois pintores do século XVI, mas também do conteúdo que expressam, a saber, as festas e ritos populares, os elementos sagrados e míticos do imaginário social e a visão do Juízo Final descrita pelo apóstolo João. Na série, essas imagens surgem ora como alusão, ora como citação, ou ainda como estilização visual e estética das paisagens presentes em representações plásticas com as quais compartilha a imagem figurativa ${ }^{9}$.

Ariano Suassuna utilizou-se do conhecimento popular do dialeto sertanejo e refrões pronunciados pelo povo simples para a construção desta que é a mais complexa de suas obras. As falas de Quaderna são representações que proveem de fontes não oficiais. São imagens que reverberam a milenar evolução da cultura popular ocidental e que são traduzidas para a cultura do Sertão brasileiro.

Quaderna sonha em criar um reino tal qual os medievais, com suas festas religiosas e as carnavalescas de aspecto popular, com seus ritos e cultos cômicos, as procissões e cortejos durante os quais se exibiam gigantes, anões, monstros, bufões e tolos, palhaços, animais sábios e sagrados; e também em retomar a literatura paródica da Idade Média. Estes elementos são estilizados na cavalgada da vinda de Sinésio Garcia Barreto e recebem um tratamento da cultura regional do Sertão brasileiro. E o estilo pelo qual Quaderna narra esta cavalgada, seu estilo régio, é uma belíssima paráfrase do de Rabelais, do qual nos fala Bakhtin ${ }^{10}$.

No mesmo texto, ele nos diz que as formas dos ritos e espetáculos cômicos da Idade Média eram, por natureza, representações de uma visão específica do mundo, do homem e das relações humanas. A festa do carnaval, por exemplo, 
reproduzia uma inversão de papéis, um deslocamento do mundo vivido para o sonhado. As formas carnavalescas eram estreitamente relacionadas às formas artísticas e animadas por imagens, estando, portanto, muito próximas ao espetáculo teatral, de modo que nos carnavais populares a própria vida era apresentada por meio de elementos característicos da representação.

Uma representação carnavalesca não é assistida, diz Bakhtin, é vivida. Festa regida pela lei da liberdade. Esse efeito de liberdade é apresentado na série com a grande tomada panorâmica do Sertão. Quaderna vive intensamente esse modo peculiar de existência. Leva até as últimas consequências a fuga dos moldes da vida ordinária, isto é, oficial. Mais do que espetáculo artístico, o carnaval é uma segunda vida, a primeira no caso de Quaderna; é um movimento de inserção temporária no reino utópico da universalidade, liberdade, igualdade e abundância.

O olhar carnavalesco manifesta-se por meio de modos de expressão dinâmicos e mutáveis, sendo, por isso, imagens líricas, concebidas pela lógica das coisas ao avesso, da face e do traseiro, pelas diversas formas de paródia, degradações, profanações, coroamentos e destronamentos, e das permutações constantes do alto e do baixo ${ }^{11}$. Voltemos nosso olhar à série e veremos a grande roda da dança, no centro da praça, como elemento cujo sentido imprime a roda maior, que é a roda da vida, também ela com seus momentos de altos e baixos, bem como o tempo circular da narrativa. Ao ser traduzida em imagens de luz e movimento, a cena também ganha visualidade por meio do giro de $360^{\circ}$ que a câmera faz em dada sequência.

No Romance d'A Pedra do Reino, Quaderna surge também como estilização da figura do juglar. Durante a Idade Média, cultivou-se em Castilha um tipo de poesia épica que narrava na língua romance - dialeto popular daquela região da Espanha - as façanhas heroicas dos guerreiros famosos da história local. A esta poesia denominou-se mester de juglaría, ou seja, ofício dos juglares. Os juglares eram homens ou mulheres que atuavam nas praças públicas ou nos palácios dos reis, para divertir o público. Este era formado não só pela gente de baixa condição social, mas também pela aristocracia feudal. O ofício do juglar era bastante amplo: poeta, recitador, cantor, bailarino, palhaço, adestrador de animais, ator, humorista. Em suas encenações, parodiavam a figura dos clérigos e reis, imitavam mendigos e vagabundos. Geralmente suas apresentações eram acompanhadas por tambores e instrumentos musicais de cordas e de sopro: flautas e o nay. Vestiam-se com trajes de coloração vistosa, alegres e chamativas. Gozavam de grande popularidade entre o público. Entre suas destrezas, destaca-se a de recitar ou cantar poemas. No entanto, supõe-se que os juglares não foram de fato poetas criadores, e sim repetidores de composições alheias, ainda que não se descarte a possibilidade de algumas das poesias por eles recitadas serem deles próprios ou modificações de outros poemas ${ }^{12}$. Ou seja, também os juglares eram tradutores.
11. Ibid., p. 9-10.

12. PIDAL, Ramón Menéndez. Poesía juglaresca y juglares. Aspectos de la história literária y cultura de España. Buenos Aires/ México: Espasa/Calpe, 1942. 
comunicação \& educação • Ano XIV • Número 2 • maio/ago 2009

\section{ALEGORIAS DO PASSADO}

Vejamos agora como as imagens agentes das festas em praças públicas e da figura dos juglares são materializadas por Pieter Bruegel. Por imagens agentes entendem-se aquelas que aludem a determinados discursos. Construídas artificialmente, são formas, símbolos, daquilo que queremos lembrar ou daquilo que queremos fazer ser lembrado. Estão inseridas em um locus, que deve ser um lugar facilmente apreendido pela memória. As imagens agentes surgiram para fins da prática da oratória. Por meio delas, os oradores memorizavam aquilo de que queriam lembrar, constituindo, pois, uma prática de memória artificial, ou uma arte da memória. Conforme Yates, todo tratado de Ars memorativa, com suas regras para lugares e imagens, com sua discussão da criação de imagens de memória, repete o plano, o tema e mesmo as palavras do Ad Herennium, manual de retórica escrito em Roma por volta de 86-82, cujo autor é desconhecido. O manual foi denominado de Ad Caium Herennium, ou Ad Herennium, que quer dizer A Caio Herênio ${ }^{13}$.

Pieter Bruegel, o Velho (1525?-69), é considerado o maior mestre da pintura de gênero do século XVI. Essa corrente tinha por característica o cultivo de

13. YATES, Frances A. A arte da memória. Campinas: Editora da Unicamp, 2007. p. 23.

14. Quadro The Peasant Dance, 1568. Oil on oak panel, $114 \times 164 \mathrm{~cm}$ Kunsthistorisches $\mathrm{Mu}$ seum Wien, Vienna.

15. Fotograma capturado da microssérie A Pedra do Reino, do diretor Luiz Fernando Carvalho.

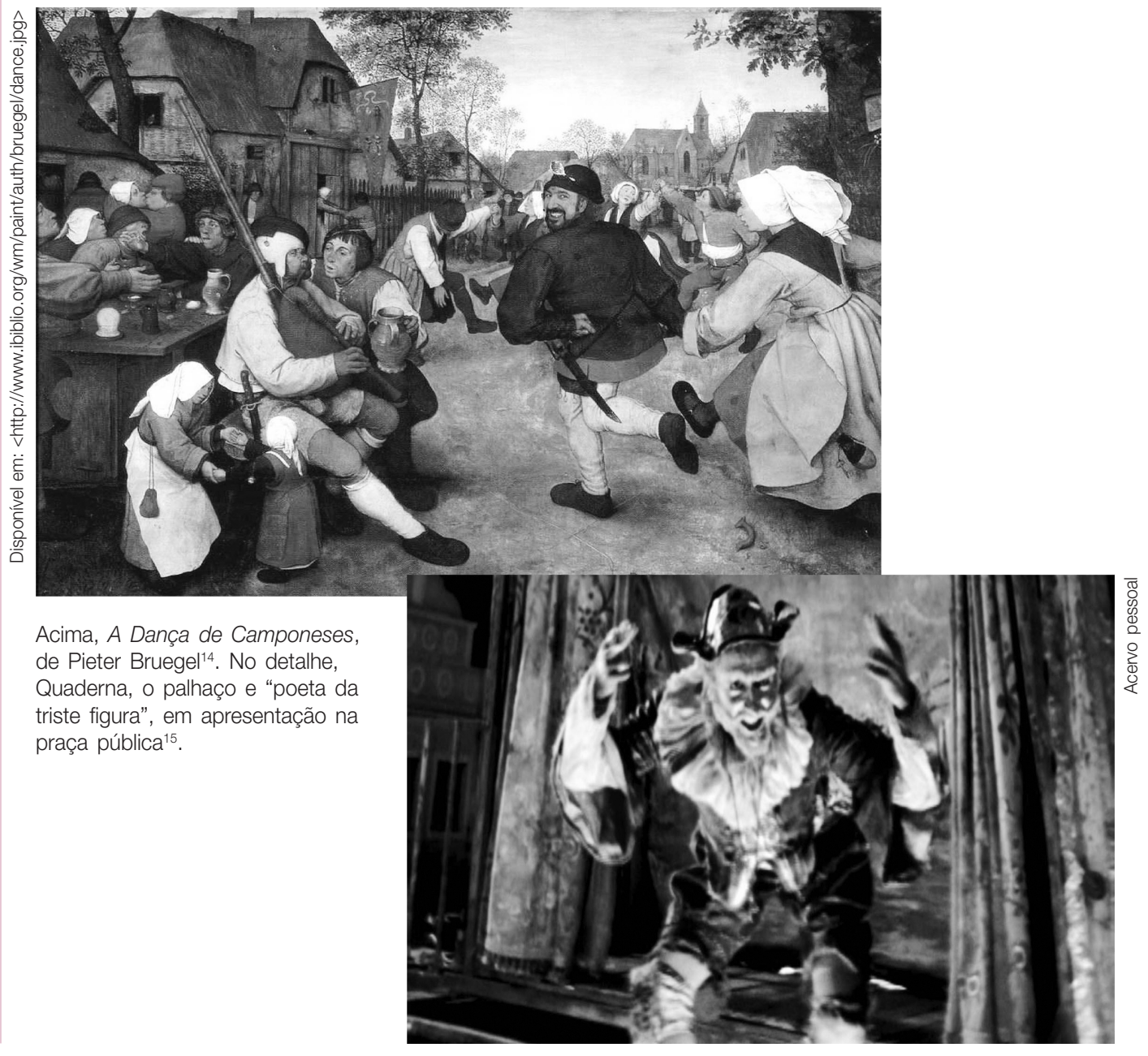


Traduções poéticas - Acir Dias da Silva e Deise Ellen Piatti

temas inspirados na vida cotidiana e popular daquele período. A pintura de Bruegel se concentrou em cenas da vida do campo. Pintou aldeões divertindo-se em festejos e no trabalho. Gombrich conta-nos que, em dado período, considerava-se o campônio uma figura burlesca, mas não esnobe ${ }^{16}$. Na vida rústica do campo, a natureza humana estava menos disfarçada e esterilizada pelo artificialismo e convenção do que na vida e nas maneiras dos cavalheiros. Este dado cultural repercute nas pinturas de Bruegel que, no desejo de mostrar a estultice da espécie humana, optava frequentemente pela representação de cenas da vida humilde e não oficial. Assim, os temas pintados por ele são cenas de celebrações festivas familiares ou festas populares na praça pública das pequenas comunidades rurais.

Ao traduzir o Romance d'A Pedra do Reino, vemos que Luiz Fernando Carvalho, ao configurar a visualidade da fotografia da microssérie, procurou dialogar com as pinturas de Bruegel, sobretudo no que diz respeito à escolha das cores dos tecidos do figurino utilizado. Há predominantemente a presença do verde e do vermelho. Também as demais cores são gritantes nas cenas pintadas, trazem vida e energia aos movimentos irrequietos do bando de foliões que dançam e bebem alegremente. É notável ainda o forte contraste entre zonas de luz e sombra.

Fiel à estrutura narrativa do romance, a série A Pedra do Reino é contada em primeira pessoa, pelo narrador-personagem. A câmera cinematográfica é o olho de Quaderna. Este expõe as imagens por meio do fluxo de consciência. A narração se dá num tempo distante ao dos fatos ocorridos: Quaderna se encontra preso numa torre, de onde observa a praça que fora cenário das peripécias pelas quais passou. Conta sua história e a de sua dinastia, desde seu bisavô, Dom João Ferreira Quaderna, o Execrável, até o momento em que ele, Dom Pedro Dinis Ferreira Quaderna, fora julgado e condenado a partir de uma denúncia que ele próprio fizera contra si, a fim de que, com a ajuda do juiz corregedor e de sua escrivã, dona Margarida, seu grande amor, pudesse escrever a epopeia do povo brasileiro. Mas o conflito central é movimentado pela misteriosa morte de seu padrinho e a saga de seus três filhos: Arésio, representante dos poderosos; Sinésio, representante e salvador do povo, esperança de uma vida de glória e riqueza aos sertanejos, e Silvestre, o filho bastardo. A vida e morte de seu padrinho e a história de seus três filhos está atrelada ao desenvolvimento da própria vida do narrador. Quaderna a rememora e a narra, simultaneamente, em quatro tempos diferentes: a época de menino; o período em que atua como palhaço na praça pública, também marcado pelo assassinato de seu padrinho e pelo seu sonho de se tornar o Imperador do Brasil; o momento do julgamento perante o juiz corregedor e, por fim, quando ele escreve sua epopeia, preso na torre. Estes quatro tempos são narrados descontinuamente, obedecendo à ordem em que as imagens são rememoradas, portanto, por vezes têm natureza de reminiscência e, por outras, de imaginação, sonho, imagens visionárias.
16. GOMBRICH, Sir Ernst História da arte. Rio de Janeiro: LTC Editora, 1999. 
comunicação \& educação • Ano XIV • Número 2 • maio/ago 2009

Na série, tais imagens oníricas surgem na forma de alusão à pintura de Bruegel, conforme sua obra A Queda dos Anjos Rebeldes (1562), e como citação de Combate de São Miguel com o Dragão (1498), xilogravura de Dürer. Vamos a elas.

A Queda dos Anjos Rebeldes é uma alegoria da origem mitológica cristã, mas sua abordagem não é nada tradicional. Ao contrário, ela apropria-se de símbolos evangélicos e os junta às imagens que expressam os horrores e alucinações trazidas do fértil imaginário medieval. Vários anjos caem a partir de um foco de luz centralizado, ao alto. Trombetas são tocadas e os anjos, mesmo com suas puras vestes alvas, travam uma batalha sangrenta com criaturas surreais e demoníacas. A cena traduz uma situação de aflição coletiva do próprio cotidiano da época do artista. A confusão é o que impera. A batalha que aí vemos

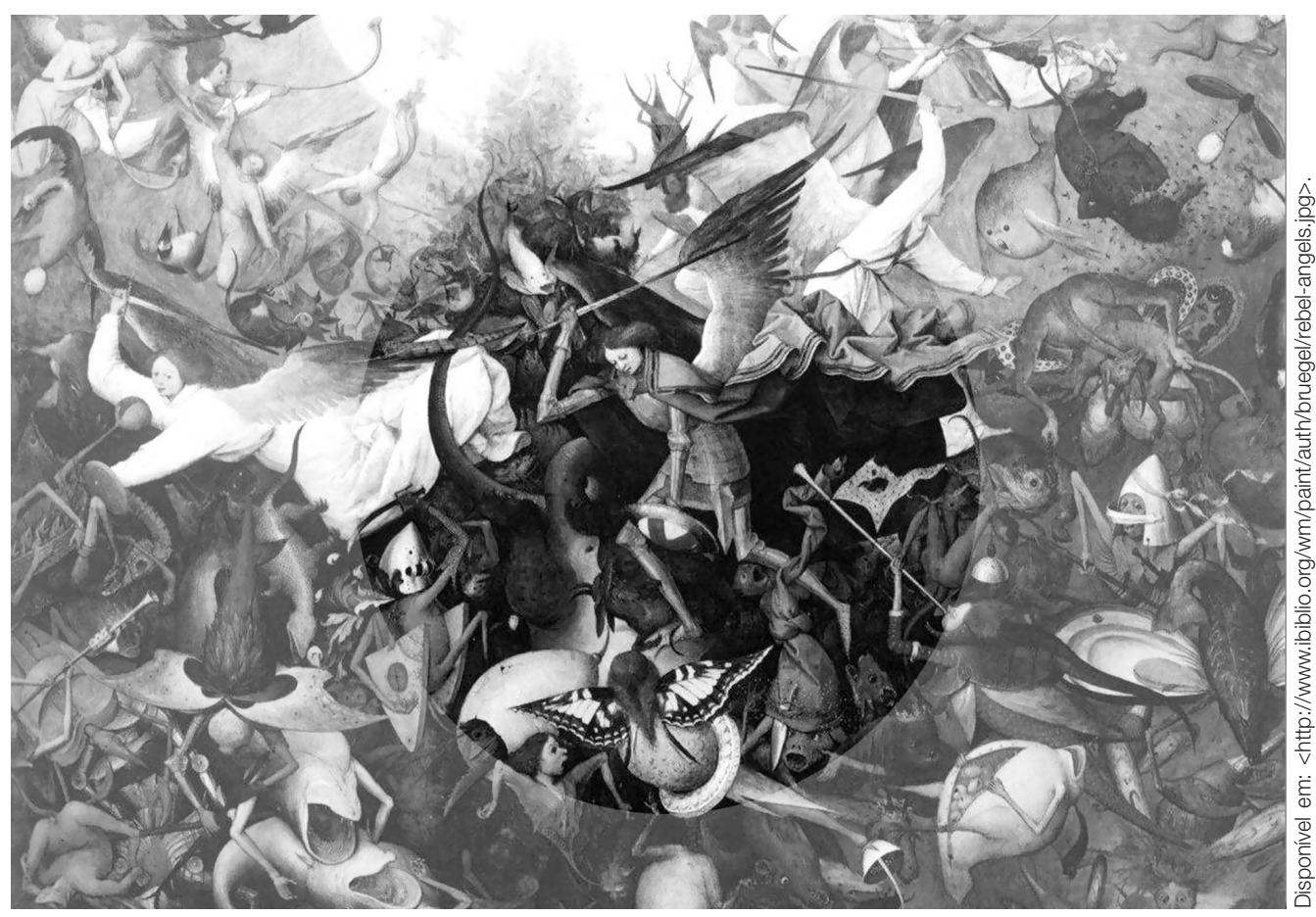

17. Quadro The Fall of the Rebel Angels, 1562. Musée des Beaux, Arts at Brussels.

18. Fotogramas capturados da microssérie $\mathrm{A} P$ Pedra do Reino, do diretor Luiz Fernando Carvalho.

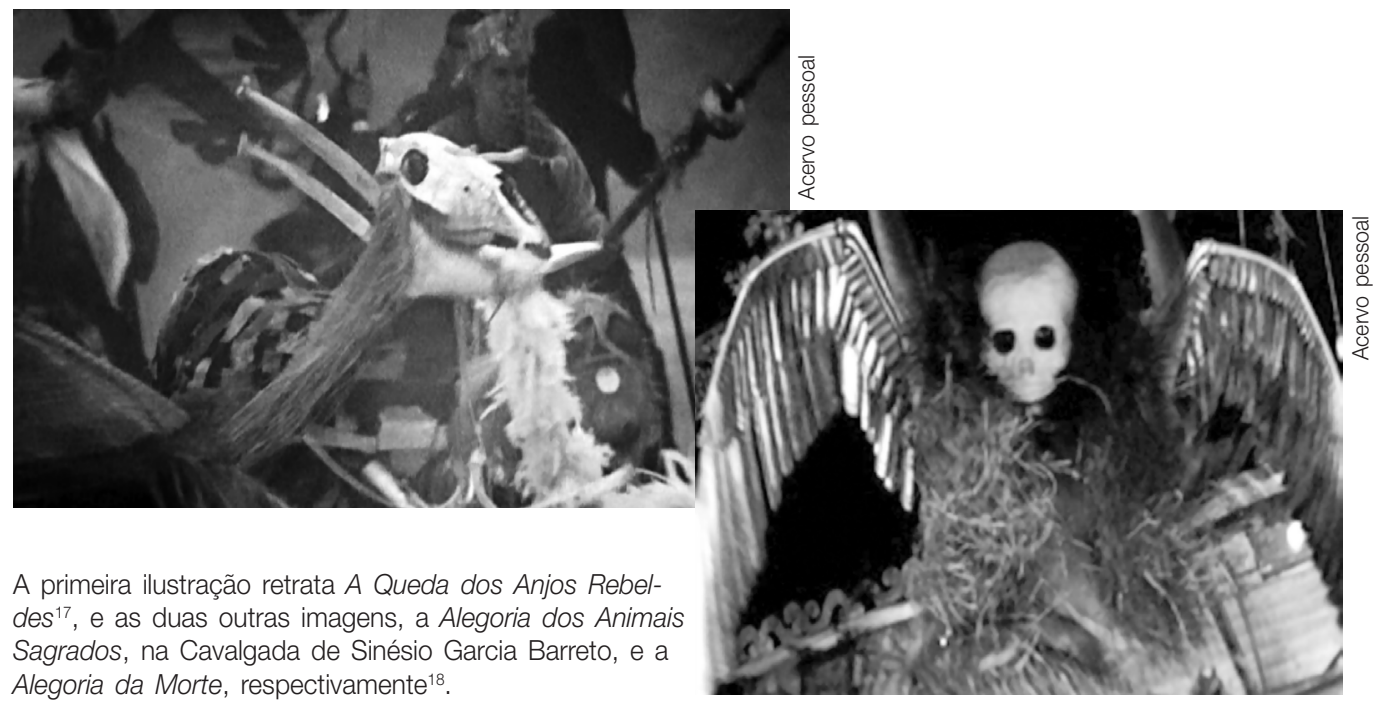


Traduções poéticas - Acir Dias da Silva e Deise Ellen Piatti

tem como referência uma das transfigurações da luta entre o bem e o mal da mitologia cristã; são anjos rebeldes em guerra com anjos de Deus. Em meio à confusão, um dos anjos ganha destaque. Ele veste uma armadura, encontra-se ao centro da tela munido de uma poderosa espada e está prestes a decapitar uma criatura diabólica.

Ora, também o cinema de vanguarda desejava constituir expressão, ou seja, buscava expressar a alma de suas personagens, em detrimento da linguagem convencional. Enquanto cinema visionário:

[...] a imaginação marca sua onipresença [...] ela é o começo, o meio e o fim do discurso cinematográfico, que é sempre um "eu vejo" na primeira pessoa e a indicação imediata do próprio exercício do olhar (para dentro) como ocasião de uma experiência revelatória ${ }^{19}$.

Em A Pedra do Reino, também vemos um modelo onírico de cinema que se faz caracterizar pela abertura para o mistério e o fantástico, elementos que, conforme Buñuel, marcam o tom no cinema de poesia ${ }^{20}$. De fato, a fotografia da microssérie está configurada de modo a permitir que aquilo que vemos possa vir a ser carregado pelos nossos afetos. Mas ainda que expresse, de modo geral, um conteúdo que provém do interior de uma personagem, este só pode ser materializado por meio de imagens do real: “'O mais admirável no fantástico é que o fantástico não existe; tudo é real', disse André Breton" ${ }^{21}$. Daí a razão de Luiz Fernando Carvalho ter buscado na memória estética imagens por meios das quais pudesse dar forma a um conteúdo que pertence ao plano da imaginação de Quaderna. Assim, a câmera surge, pois, como exteriorização de visões interiores, do olhar e da memória do narrador-personagem, bem como do diretor da obra. A luz que reflete as imagens de A Pedra do Reino está carregada de mitos antigos, traduzidos muitas vezes, e também dos novos, criados pela atividade mito-poética do cineasta: a inserção de alegorias (cavalos que não são animais, mas bonecos, monstros na forma de caveiras etc.) converge em fator que perturba a percepção naturalizada do espectador, revelando-se, pois, enquanto projeto estético e político do diretor. Também a variação de luz - foque/ desfoque -, com seus movimentos rápidos e irregulares feitos com a câmera na mão, convida o espectador da microssérie a uma experiência sensorial que o arranca de uma atitude cotidiana de apreciação. Ante a linguagem poética, o papel do espectador é o de, por meio da brecha criada pela desintegração do espaço dramático e narrativo, chegar à apreciação estética para além do evento imediato focalizado e ver a expressão de um estado de alma.

Também em Dürer, Luiz Fernando Carvalho buscou equivalência visual para a construção das visões que o personagem Lino Pedra Verde teve do combate travado entre o Cavalheiro Diabólico e o Cavalheiro do Bem.

Albrecht Dürer (1471-1528) é considerado o maior artista alemão do início do século XVI. Ainda menino, Dürer revelou um surpreendente talento para ilustrações xilográficas. Na vida adulta provou que tinha mais do que meros conhecimentos técnicos dessa difícil arte. Dentre as suas primeiras grandes
19. XAVIER, Ismail. O dis curso cinematográfico: a opacidade e a transparência. 3. ed. São Paulo: Paz e Terra, 2005.

20. XAVIER, Ismail (Org.) A experiência do cinema: antologia. Rio de Janeiro: Edições Graal/Embrafilmes, 1983. p. 335.

21. BUÑUEL (1970), apud XAVIER (Org.), A experiência do cinema, cit. p. 337. 
comunicação \& educação • Ano XIV • Número 2 • maio/ago 2009

22. GOMBRICH, História da arte, cit., p. 345 .

23. Xilogravura St. Michael's fight against the dragon, $1498 ; 39.2 \times$ $28.3 \mathrm{~cm}$.

24. Fotogramas capturados de A Pedra do Reino, do diretor Luiz Fernando Carvalho. obras, destaca-se uma série de xilogravuras para ilustrar o Apocalipse de João. Nelas o artista imprime com tamanha força as visões aterradoras do Juízo Final e dos sinais e prodígios que os precederam, como jamais haviam surgido antes. Conta-nos Gombrich que, inseridos no contexto do final da Idade Média, Dürer e seu público manifestavam interesse crucial às visões fantásticas dos eventos apocalípticos, pois eram muitos os que esperavam que tais profecias se concretizassem ainda durante suas vidas. A figura que segue mostra uma ilustração do fragmento de Apocalipse 12,7: "Houve peleja no céu: Miguel e seus anjos lutaram contra o dragão; também pelejaram o dragão e seus anjos; todavia, não prevaleceram; nem mais se achou no céu o lugar deles"22.

Ao dar forma visual a esse grande momento, Dürer desprezou as tradicionais poses de elegância e desenvoltura que eram repetidamente usadas para materializar o combate do herói com um inimigo mortal. O São Miguel de Dürer não faz pose. É de uma seriedade terrível. Usa as duas mãos num grande esforço para enterrar a lança na garganta do dragão, e seu gesto poderoso domina toda a cena. À sua volta estão as hostes dos outros anjos guerreiros, combatendo com espadachins e arqueiros contra monstros diabólicos cuja aparência fantástica desafia qualquer descrição. Abaixo desse campo de batalha celestial, estende-se uma paisagem límpida e serena.

Essa ilustração de Dürer surge na série sob a forma de citação visual e estética, e consequentemente Luiz Fernando Carvalho alude à ideia do conflito entre o Cavalheiro Diabólico e o Cavalheiro do Bem, representados alegoricamente na obra de Dürer como São Miguel e o maligno dragão.
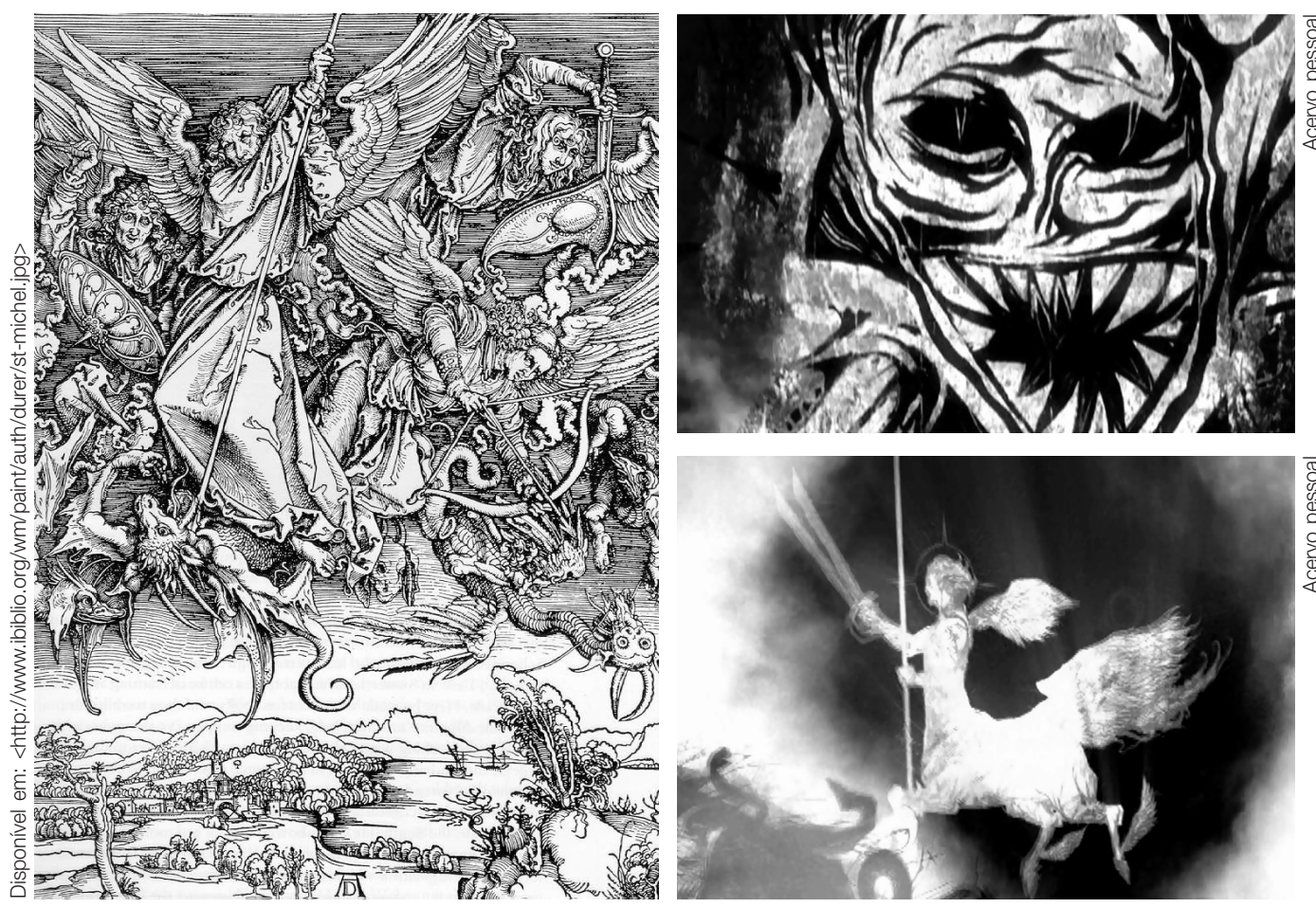

A primeira ilustração representa o Combate de São Miguel com o Dragão, de Dürer ${ }^{23}$, e as duas outras imagens, a visão de Lino Pedra Verde do combate entre o Cavalheiro Diabólico e o Cavalheiro do Bem² 


\section{REFERÊNCIAS BIBLIOGRÁFICAS}

ALMEIDA, Milton José de. Cinema: arte da memória. Campinas: Autores Associados, 1999.

BAKHTIN, Mikhail. A cultura popular na Idade Média e no Renascimento: o contexto de François Rabelais. Brasília: UnB/Hucitec, 1987.

BENJAMIM, Walter. Magia e técnica, arte e política: ensaios sobre literatura e história da cultura. São Paulo: Brasiliense, 1994.

EISENSTEIN, Sergei. A forma do filme. Rio de Janeiro: Jorge Zahar, 2002.

GAGNEBIN, Jeanne Marie. História e narração em Walter Benjamin. São Paulo/ Campinas: Perspectiva/Fapesp, 1994.

GOMBRICH, Sir Ernst. História da arte. Rio de Janeiro: LTC Editora, 1999.

LEITE, Sebastião Uchoa. Jogos e enganos. Rio de Janeiro: Ed. 34, 1995.

PIDAL, Ramón Menéndez. Poesía juglaresca y juglares. Aspectos de la historia literaria y cultural de España. Buenos Aires/México: Espasa/Calpe, 1942.

SANT'ANNA, Affonso Romano de. Paródia, paráfrase e cia. São Paulo: Ática, 2006.

SUASSUNA, Ariano. Romance d'A Pedra do Reino e o Príncipe do Sangue do Vai-e-Volta. 5. ed. Rio de Janeiro: José Olympio, 2004.

XAVIER, Ismail (Org.). A experiência do cinema: antologia. Rio de Janeiro: Edições Graal/Embrafilmes, 1983.

O discurso cinematográfico: a opacidade e a transparência. 3. ed. São Paulo: Paz e Terra, 2005.

YATES, Frances A. A arte da memória. Campinas: Editora da Unicamp, 2007. 


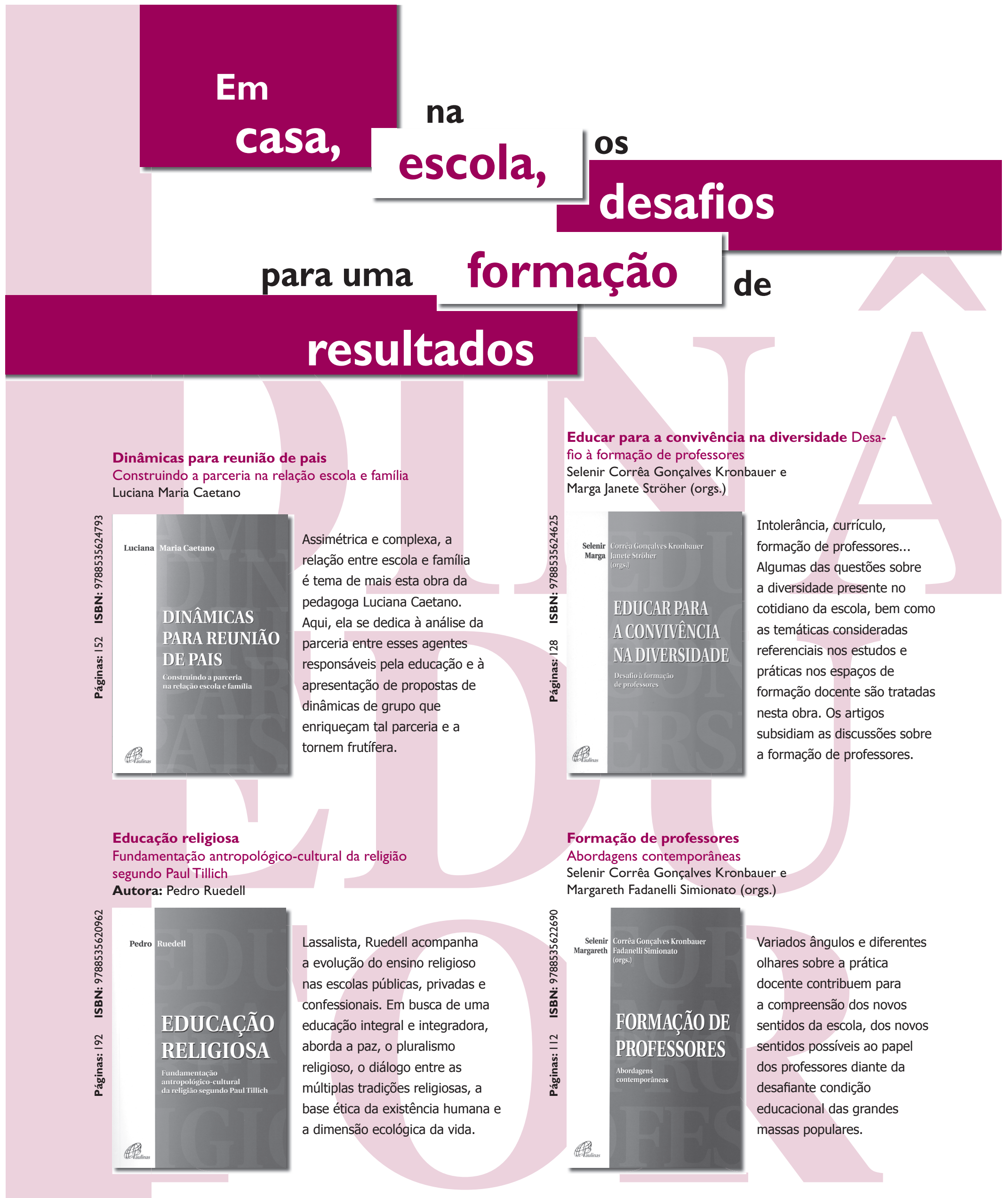

À venda na Rede Paulinas de Livrarias Se preferir, ligue 08007010081 ou acesse www.paulinas.org.br 